\title{
From Weft and Warp of Weaving to Churning of Grinder: \\ A Diasporic Trajectory in Amitav Ghosh's \\ The Circle of Reason
}

\author{
UMME KULSUM
}

\begin{abstract}
Shameless, shameless insubstantial cloth, nature's mirror, carrying on its conscience the curses of the exiled princes who, swathed in thirty yards of it, had stepped into his father's court, for all the world to see, mother naked and beautiful. (Ghosh 71)
\end{abstract}

\begin{abstract}
Amitav Ghosh's first novel The Circle of Reason (1986) demonstrates the relationship between different discourses of knowledge (Science, History, Anthropology) and its colonial application to specific localities that authenticates key strategic policy to determine world trade and economy. In particular, the novel reflects how the emergence of science and textile mills shifts the paradigm of 'weaving world' into the 'rubric of construction' business. This paper focuses on how this manipulative change in world trade and economy predetermines the influx of people from one area to another with their existing skill (weaving) and profession. This paper examines three multicultural cities of three different localities that represent diasporic lives with all their struggle, potentiality, hybridity, mimicry and ambivalence. It will also highlight on how border-business, like trafficking, smuggling, is another important issue that creates newer trajectories for more profitable business (oil, bomb, gold, hashish) that encourages displacement of people. The character of Balaram, one of the major characters of part one of the novel, will be explained as a mimic character as he represents the colonial application of science in this subcontinent. Balaram has been presented according to Homi K. Bhabha's 'Of Mimicry and Man: The ambivalence of colonial discourse' (121). And the diasporic cities like Lalpukur, al-Ghazira and El Oued can be
\end{abstract}


explained from Homi K. Bhabha's, 'Cultural Diversities and Cultural Differences.'

Amitav Ghosh's first novel The Circle of Reason (1986) explores the paradigm shift of world trade and business. It reveals how a 'weaving world' turns into a 'construction world'. This paper focuses on the influx of people during this change in world business. It also shows how colonial application of science and knowledge legitimizes the change and movement of people. This book is divided into three parts and each part deals with three different multicultural cities that are in a way result of diasporic movement. In part one Balaram, a school teacher is represented as an outcome of colonial application of science who finally seeks refuge in pseudoscience. The central character Alu, Balaram's nephew is caught behind misuse of science and malpractice of law. He is represented as an emblem of weaving world who crosses border after border and gets locked inside 'anajma' of al-Ghazira a newly built construction building. This paper aims to find out a link between Balaram and Bhudeb Roy's activities and Alu's movement from his place to three multi-cultural cities like Lalpukur, al-Ghazira and El Oued.

Homi K. Bhabha in his essay 'Of Mimicry and Man: The ambivalence of colonial discourse' says "mimicry emerges as one the most elusive and effective strategies of colonial power and knowledge" (122). The character of Balaram in The Circle of Reason appropriates Bhabha. The effect and acceptance of Science in this subcontinent is presented through the character of Balaram in The Circle of Reason. Balaram was educated in Colonial Indian Sub-Continent, he joined in Amrita Bazar Patrika in 1936 and became the dumping ground of West. In part one, the incident of $11^{\text {th }}$ January, 1950 hints the inception of newer strategies in 3 year old infant India, by western world. A group of scientists including Madam Juliot-Curie visited India to open the Institute of Nuclear Physics. Being mocked at for his illogical questions to Joliot-Curies, Balaram, other than going into the main stream of the science chooses a tattered book from the street "Practical Phrenology" which is actually a pseudo-science. Balaram's displacement from science to pseudo-science authenticates colonial application of knowledge in this subcontinent as "mimicry represents an ironic compromise" (Bhabha 122). Eventually, in Lalpukur, Balaram uses carbolic acid (symbol of Science) to fight against germs of the refuge shacks. And this carbolic acid is instrumentally used to light fire against Bhudev Roy that 
forces Alu to leave his land. Here Ghosh gives us clue about the application of science in this subcontinent that has been manipulated by colonial power to fulfill their future plan to ensure their flow of trade. As Robert Dixon says, " . . Ghosh has moved further in the direction of global theory than in The Circle of Reason, where the flow of trade was over determined by an asymmetrical economy of power that favoured Western interests" (15).

The central character, Alu, was forced to move from Lalpukur because of Rakhal's terrorist activities. Rakhal, Shombhu Debnath's son learns how to make bomb instead of weaving because it has market in war and it is more profitable. Colonial misrepresentation of science has again been reflected by Rakhal who symbolizes the change in trade. This deliberate change works in different ways; firstly, it distorts the already established professions and institutions. And secondly, it forces the mass exodus of people from one area to another for searching newer trade that causes diaspora.

Claire Chambers in her essay 'Historicizing Scientific Reason in Amitav Ghosh's The Circle of Reason' says, "Knowledge is produced by structures of dominance, particularly the military, economic, and epistemic strategies of colonialism" (37). In The Circle of Reason the discourse/science of Criminology has also been questioned. The police officer Jyoti Das and his senior officials appropriate their lack of knowledge in every action they take. Though Jyoti Das, a young Assistant Superintendent, understands the case of Alu is not that serious and can be handled by local police force, his senior boss DIG of police thinks like the conventional myth of border people. DIG entertains Bhudeb Roy's make beliefs and represents common people's attitude towards border people. The notion is explicit when Bhudeb Roy says:

This is a border area, which is why the case was given to you people in the first place. Haven't I told you they're receiving guns from across the border? You have to do something. What does the government pay you for? (Ghosh 131)

Ghosh here raises the question of re-reading the discourse of law that should be supportive to human being other than misleading and it being corrupt and biased by some power grid. Alu is grinded into pieces in the mechanisms of law who seeks 
refuge from place to place. The perpetual gap between truth and reality is expressed while Bhudeb Roy gives his complete personal opinion about Balaram Bose and his activities, as he says:

... that a retired school master in his village was being used by a foreigntrained agent of some kind, disguised as a weaver to run a network of extremists. There were so many refugees in those border areas and they are good clays for anyone's hand. (Ghosh 126)

The use and application of law was completely manipulated by colonial power and Alu and Balaram were victimized.

The Circle of Reason (1986) is an authentic manifestation of Indian diaspora, its causes and consequences in three different social and political settings. It can be said as a composite formations made up of many journeys to different parts of the globe, each with its own history, its own particularities. The book starts in West Bengal, goes throughout the whole India, rests somewhere in Middle Eastern city al-Ghazira, El Oued of Algerian Sahara and ends in Tangier. "It abounds in bizarre moments but is basically a serious attempt to deal with man's delusive quest for reason and with the contemporary diaspora that has taken countless Third world workers and professionals across continents in quest of a better life" (Alam140). The book highlights the predicament and social condition of people that they are not always responsible for, rather are victims of, specially women and children who belong to marginal line in any society of the world, when they are forced to cross the border. Because for them 'border is the only hope' and 'hope is the beginning' of anything. Ghosh deals both with professional migrants and subaltern types but focuses more on the latter in The Circle of Reason and tries to figure out the grudge they bore against the world because they were not qualified for more prestigious services in the examinations. Along with the multicultural diasporic situation the book discloses how 'extremists are concocted' (39) and produced with the help of conventional discourses to 'wangle trips abroad at government expense' (Ghosh 60).

The book is divided in three distinct parts and every part deals with the theme of diaspora differently. The first part "Satwa: Reason", consists of nine chapters, starts 
with the arrival of the central diasporic character Alu, in Lalpukur, a town near Kolkata, and ends with his another arrival at one of the Middle East's fictitious towns al-Ghazira. Part two "Rajas: Passion" of ten chapters describes a group of working class people's hybridized lives end in a brutal, terrific bloodshed including two deaths (Abu Fahal and Karthamma) when with the help of merely luck a part of "Zindi folk" along with Alu could manage to get into Zeynab spending sometime in Egypt and Tunisia, while Virat Singh the 'nakhoda' or boatman, helps them to reach Algerian desert town, El Oued. And lastly, Part three "Tamas: Death" consisting of three chapters makes the circle of reason full with Kulfi's death rituals (using carbolic acid in place of Ganga Jal) and ends again with Alu, Zindi and Boss on road walking and waiting for the ship of Virat Singh that will carry them home. The whole novel moves in four hundred and twenty three pages that starts with arrival and ends in departure and as a whole it can be seen as a picaresque novel that sews many tales of diasporic location and dislocation with different political and cultural conditions. In The Circle of Reason Ghosh wants to discover and correlate if there is any link among the different incidents happening simultaneously in different corners of the world. Certain historical events, such as the Indian nationalist struggle in 1930s, the independence war of Bangladesh in 1971, and the international tide of migration to the Middle East in 1970 and onwards, are foregrounded in The Circle of Reason. Balaram's birth year 1914 has also been seen from world's perspective and some incidents have been mentioned that has a direct link with the history of Indian diaspora.

Homi K. Bhabha in his essay 'Cultural Diversity and Cultural Differences' says:

Cultural diversity is the recognition of pre given cultural 'contents and customs, held in a time frame of relativism; it gives rise to anodyne liberal notions of multiculturalism, cultural exchange or the culture of humanity. Cultural diversity is also the representation of a radical rhetoric of the separation of totalized cultures that live unsullied by the intertextuality of their historical locations. (206)

The multiculturalisms of Lalpukur can also be seen as a mixed culture of Bruce Lee and Hindi movies, schools of kung fu, language mixed up with Noakhali, 
Burmese, and West Bengal accent. As Ghosh writes the village is 'churning like cement in a grinder' (Ghosh 27). For each aspect of Lalpukur culture authenticates diasporic movement from their different historical movements.

The first part relates some incidental factors on Indian diaspora. For example, the writer connects 1914, Balaram's birth year to the crucial moments in Indian immigration to the west, like the day when an American judge mulled over the "second-ever application by a Hindu for citizenship in the United States" and decided in favour of admitting the Aryan, or the day when Canada's colonial Government decided not to admit:

... eight thousand Indians on board Kamagatamaru back from Vancouver, after deciding that the ancient racial purity of Canada could not be endangered by Asiatic immigration. Or at much the same time, there was the date of the launching of a drive by the imperial government to recruit Indians for an expeditionary force to join Algerians and Vietnamese and Senegalese in defending the freedom of the Western world from itself. (Ghosh 39)

This was the time when the First World War was seen in Europe with assortment of massacres and butchery. We see how Indian people's movement was overpowered and exploited by western world, politics directly worked on making diasporic condition.

Dividing the Indian Sub-Continent into pieces was a parting gift by Imperial British Government. It was first Pakistan and India, a division merely on religion, and afterwards the East Pakistan and West Pakistan finally ended on giving birth to Bangladesh. During each partition there was movement of people and religion was used as a deciding factor for movement. In each case we find as history supports, basically people of Hindu religion felt like to migrate in India from both parts of Pakistan and as same Muslims thought Pakistan as their safer abode and migrated to Pakistan from India. Gosh's The Circle of Reason's Lalpukur was such a place that was inhabited by those diasporic people. He says:

They had immigrated to India in a slow steady trickle in the years after East Bengal became East Pakistan. Most of them had left everything but their dialect 
behind. It was a nasal sing-song Bengali, with who knew what mixed in of Burmese and the languages of the hills to the east? Many of them had learnt the speech of West Bengal, but it had only made their own dialect more dear to them--- as a mark of common belonging and a secret weapon to confuse strangers with. (Ghosh 27)

And again when East and West Pakistan were at war another flow of people was 'vomited out' or migrated 'from remote district of Noakhali, in the far east of Bengal close to Burma' to Lalpukur. For them "border dissolved under the weight of millions of people in panic-striken flight from an army of animals" (Ghosh 60). So we can consider Lalpukur as a place for diasporic location and dislocation as word diaspora is paradoxical from its birth.

Lalpukur is a place where nothing important really happens. "Lalpukur could fight no war because it was damned to a hell of longing" (Ghosh 57). They engage all their potential of life in thinking what they have lost, how they have become almost have-nots despite of having all those lavishness of life left over in the other part of the border. "Their only passion was memory; a longing for a land where the green was greener, the rice whiter the fish bigger than boats . .." (Ghosh 60). The memory and moaning of lost home has seized away all their saps of lives. "It is nothing but a dumping-ground for the refuse from tyrants' frenzies" (Ghosh 61). They are the victim of political partition between the two Pakistans. The emergence of new nation somehow displaces them from their country of origin, makes their life uncertain and vulnerable placing them within the term 'refugee'. The present condition of the people of Lalpukur raises the question of what nationality means and how it affects the mass psychology of migrants. They are forced to a situation they are not ready to face and are victims of political power play of two parts of Pakistani nationalist leaders.

On the other hand, these bundled belongings of burst boundaries of Lalpukur become economically profitable for Bhudeb Roy. His rice fields sprout shacks of packing wood and corrugated iron. "He had discovered that rents from refugee shacks yielded a better harvest than rice" (Ghosh 60). The tea stall under the banyan tree turns into vegetable vendors and grocery shop. Bolaida starts his new business 
of stocking corrugated-iron and sheets of tin beaten out of discarded kerosenecontainers. Bhudeb Roy and Bolaida take the migrant people of Lalpukur as a source of their income generating factor, which is an important issue we find in conditioning the predicament with diasporic people as sometimes their predicaments are deliberately created for the cause of economical check and balance. The activities of Rakhal, Shombhu Debnath's son, can also be mentioned here as he dreams to be rich by selling bombs in war. "They're bombs, he said. Bombs ... Alu said what will you do with them? Make money he answered. There's a good market for them. Because of the war, you know" (Ghosh78). We can anticipate how Ghosh here tries to show a link between war, border, terrorism and world economy and it is the diasporic people who perpetually pay off the price like Nabeel (In an Antique Land), Kulfi, Abu Fahal, Karthamma (The Circle of Reason), Tridib, Jethamoshai (The Shadow Lines).

The hybridity of diasporic language is shown while Shombhu wants to teach weaving to Alu. Ghosh declares loom and weaving as true migrant phenomena that binds the world other than tearing apart. Shombhu becomes junk with words from different places, from varied languages. Ghosh says:

So many names, so many words, words beaten together in the churning which created the world: Tangail words, stewed with Noakhali words, salted with Nabogonj words, boiled up with English ... Loom crosses borders with weaver depending upon world economy. 'On a loom a beam's name changes after every inch. ... A loom is a dictionaryglossarythesaurus. . . . it is because the weaver, in making cloth, makes words, too, and trespassing on the territory of the poets gives names to things the eye can't see. That is why the loom has given language more words, more metaphor, more idiom than all the world's armies of pen-wielders. (Ghosh 74)

This loom, cotton, cloth changed the world's trade history while men were driven mad for machine. Ghosh tries to discover the position of Alu and his long acquired skill while:

Lancashire poured out its waterfalls of cloths, and the once cloth hungry and peaceful Englishmen and Dutchmen and Danes of Calcutta and Chandannagar, 
Madras and Bombay turned their trade into a garrote to make every continent safe for the cloth of Lancashire, strangling the very weavers and techniques they had crossed oceans to discover. Millions of Africans and half of America were enslaved by cotton. (57)

The other people's attitude about border people and positioning them in a complicated space is more vivid in Maya's uttering, "Yes kill us all, we are all weapons" (144). The gap of being united with the people of West Bengal and their rejection of taking the 'refugees' to the main stream, and the space of the migrant identity is exploited by many powers who make them prey and brew anything profitable for the manipulator. The potentiality of diasporic people and border people is also susceptible to human greed and materialism of power play.

Alu's journey from one place to another can be compared to cat's cradle as he changes his destination centering on sewing machine or the skill he thinks he has learnt. He first goes to Hazra road, Kolkata, Gopal's house. He passes a couple of days in companion with Rajon, a tea stall boy, who comes from Kerala's great caste of Chalias who for centuries have woven and traded in simple white cloth and for searching weaving he proceeds south and south and finally reaches to Mahe'. From then on Alu is on board to Mariama where he meets with many other people of the same kind who actually leave India with a hope for better life that their country fails to offer. This is a regular business of that area where people are actually dreamy about the other side of the border and think that the other strand can help them to earn their livelihood better. The ship Mariama symbolizes those helpless people's movement from one place to another with various intentions depending on their predicament. We find different types of characters from remote corners of the world and it becomes a microcosm of working class migrant people. We meet Sajjan, 'a lean, sunken-cheeked boy, not yet sixteen', Haji Musa Koya, with wispy white beard whose profession is to help the people crossing the Indian Ocean by taking three times more than usual fare. Alu gets acquainted with two other male passengers named Rakesh, the sales person, and Professor Samuel. Among the female there are Karthamma, Kulfi, Chunni and Madam Zindi, who is a women trafficker. They are all the 'boat people' rather than suited- booted and university graduate skilled migrants of today's urban world who used to migrate as 
professionals with proper work permit, dollar endorsed and recruited by Trans National Corporations. They are lower class working people who are victimized by their social position and are exploited by the cheap labour hunters. Though we do not get any direct encounter with border vigil and police on their way to alGhazira, Hajji Musa's deliberate painting of Mariama as 'nondescript bluish grey' establishes the fact that their work is illegal. "When Hajji Musa had decided to turn Mariama to the lucrative al-Ghazira trade he had had her painted a nondescript bluish grey in the hope that it would make her less visible to coastguards and harbour police" (Ghosh 169). This business of labourer trafficking mostly of women is a profitable business. Though the risk factor is high and Haji Musa's rate is more than others, still there is never any scarcity of passengers. They are also the sources who transect illegal drugs and fuels that help them heaping up huge amount of money. Hajji Musa is one of them.

His overheads he covered by a little discreet trafficking in the highly priced hashish of the Idikki hills. And he always carried enormous quantities of diesel fuel: apart from the mounds of jerry cans below deck, there were a few drums in the cabin and a couple in the stern which also served a curtain off a plastic slop-bucket. (Ghosh 170)

Amitav Ghosh's The Circle of Reason's second part vividly portrays their diasporic life with various problems and difficult situations they encounter every day, where finally two of them were even killed. This part shows how third world working diaspora group is forced to change their strategy towards life, negotiate every moment with their ever changing identity though they are long way to understand that. We find the attitude of Government regarding them from Professor's speech while all of them were literally stuck up in middle of the sea. "Bringing helpless men and women out to die like animals on the sea. Why is the government not doing something?" (Ghosh 175). The role of state is also very ironical as they do not get any support from any immigration office while sometimes a third world country's economy depends upon the money they send to the country.

The previous history and predicaments of the characters, for example, the storries of Karthamma, the story of Rakesh, story of Professor Samuel reflect 
different socio-economical causes for Indian diaspora. For example, the pregnant passenger Karthamma who looks like doing 'eight-ana jobs in the rice fields and things like that' epitomizes the real reason for 'Third world working class' migration, movement for attaining economical security that can make her life, and may be her future generations' life better at any rate. She has been lured to alGhazira by someone who made innumerable fake promises, "your child will be this, it will be that, it'll have houses and cars, and multistoried buildings, it will be a Ghaziri" (Ghosh 177). She heard she had to complete some forms for attaining those facilities, if not, her child will be back in India. She would rather kill it than allow that to happen; kill it right now with a bottle while it is still in her womb. But considering all these situations Gosh is really concerned about "Where do these villagers get these ideas? Khan Se?" (Ghosh177). I think a satisfactory answer will reveal more facts about Indian diaspora. While Professor Samuel indirectly indicates Zindi, she angrily answers, "She (Karthamma) begged me, she even offered me money, to take her away from India" (178). After a while she clarifies her position and she confesses that "I take only good girls - clean, polite, and hard working. That's why I have to go to India myself to look" (Ghosh 181).

Rakesh's story discloses the frustration of his lost job that can also be linked with contemporary world's business values that destroy India's traditional business motives. Rakesh was working as a salesman for a small Ayurvedic pharmacy in Bhopal which specialized in a patented herbal laxative. He got the job after finishing his graduation in commerce and continued for six months. But:

People no longer wanted Ayurvedic laxatives. There was no market for black viscous liquids in old rum-bottles; they wanted sparkling, bubbling salts which dissolved in water, or milky syrups in bottles with bright labels. They wanted advertisements and slogans which promised more than mere movement--promotions and success at work, marital triumph, and refrigerators in their dowries. Regularity, balance and inner peace no longer sold. (Ghosh 182)

And the ultimate result of all these affected Rakesh's life and he threw the rest laxatives into the Narmada and within a month he sold his share of land and decided to leave the country desperately. 
Zindi at-Tiffaha of Ghosh's The Circle of Reason, is a very strong and interesting character who comes from Egypt 'as a young and buxom-beauty'. She always stands 'under a red printed umbrella' and is presented as a broker between two cultures. Her communication in many languages like Hindi, Arabic, English and her strong personality, quick decision making prove her competent in her 'women herding' profession. Zindi's the apple's house was the place where all displaced peoples from different corners of the world were put together like a family where "trousers, lungis and jellabeyyas hung from pegs on the wall and wet clothes dripped on a line which ran from one barred window to another" (Ghosh 197). Along with the people of Mariama we find Zaghloul, Abu Fahal, Abusa, and Mast Ram who comes from remote north Indian hills. The story of Mast Ram reveals how Indian workers are cheated by recruiting agent that sometimes ends in terrific violence.

Once they were in al-Ghazira, Mast Ram found himself with only a third part of the wage that he had been promised in his pocket, for the contractor took all the rest. Mast Ram was young enough to burn at the injustice of it. . . . In front of all the others he flew at the contractor's throat. That was how he found himself with his skull split half-open, without a job, without a place to stay, and blood all over his clothes. (Ghosh 202)

The incident of losing job of Kulfi in a well-off family shows how cultural biasness and misconception adds salt to dispora-wound life. It was completely a matter of misunderstanding from both the parts and the ultimate result is suffering. Their illiteracy and language barrier made the situation worse. While the grandmother asks Kulfi with the help of the house lady, Kulfi's little knowledge in Arabic like 'too hot' and 'more salt' could not help her from being in the street right after few moments. They were trying to show her something with sign language and the grandmother acts it out, but nervous Kulfi was 'trapped inside' that language. Professor Samuel also faced the same kind of losing job incident and he was even arrested by the police. It was also an incident of misunderstanding and cross cultural gap. On that day Professor went to his work place which was a super shop (where he was an accountant and assistant to the manager) wearing a starched white 'lungi' as all his trousers were untidy and dirty. While he was thinking about 
the location of 'gambari' he unmindfully folded his lungi up to his knee and noticing his hairy bare leg, one of the rich Arabian female customers swooned and both of them were dipped inside the lake of American red tomato sauce. This is undoubtedly again another strange moment that a migrant has to face very often. And finally "there's at least one shop in Hureyya now which will never hire an Indian again" (209-10). All these incidents establish the facts of diaspora experiences that express their marginal and vulnerable position in a different social order.

The owner of 'The Durban Tailoring House', Jeebanbhai Patel, with his spade teeth and bundled-up wife reached al-Ghazira from the distant land of Durban, South Africa. He was forced to leave his country because of his secret marriage to Bohra Muslim girl as he was a Guzarati Hindu. His diasporic disposition reflects another business route through which the chain of Indian merchants come to Mozambique, then Dar es Salaam, then Zanzibar, Djibuti, Perim, Aden and finally to al-Ghazira. "It was a merchants' paradise, right in the centre of the world, conceived and nourished by the flow of centuries of trade. Persians, Iraqis, Zanzibari Arabs, Omanis and Indians fattened upon it and grew rich" (221). Through these, Jeevanbhai type of people, the 'Malik' of the mud fort who stays behind the Great Hill, started new kind of business and it has been heard that 'he took his dues and disbursed a part of them in turn when British gunboats paid their visits to the little harbour' (221). Though Jeevanbhai Patel was a rich person in alGhazira, people around him never accepted him and never let him into their houses. All his life, Jeevanbhai 'circled just beyond the thresholds of respectability.' He started with a cloth-shop, switched to dates and general groceries, then changed to hardware and later to carpets in his first decade and it changed almost in every year. It was in a little room behind the shop that Jeevanbhai's real business was held. In his little back room Jeevanbhai spun out his web, spanning oceans and continents, and such are the ironies of fortune that he, whose marriage has cast him out of his family, found fame as the most successful marriage-broker in the Indian Ocean. As his 'marriages' blossomed and grew rich in progeny, Jeevanbhai grew rich with his bridal pairs, for he had another talent, he had learnt the secret of spinning gold from love. He went into the 'gold trade' between India, al-Ghazira 
and Africa. Soon he began to diversify, first into silver, then a few guns. That was when he first began making his trips to the Old Fort. We can find a similarity between Rakhal and Jeevanbhai Patel as they are made crazy for money forgetting about their values, out of diasporic condition.

Diasporic dimension of al-Ghazira takes a new turn when it was turned into an oil town as Nury the Damanhouri describes:

... from the other side of the fence, faces stared silently out---Filipino faces, Indian faces, Egyptian faces, Pakistani faces, even a few Ghaziri faces, a whole world of faces. Since the beginning of time al-Ghazira has been home to anyone who chooses to call it such---if he comes as a man. But those ghosts behind the fence were not men, they were tools---helpless, picked for their poverty. In those days when al-Ghazira was still a real country they were brought here to slip between its men and their work, like the first whiffs of an opium dream, they were brought as weapons, to divide the Gaziris from themselves and the world of sanity ; to turn them into buffoons for the world to laugh at. (Ghosh 261)

We can easily find the third world diasporic communities here among those ghosts whose predicaments have been used and exploited by different power playing agents.

Alu was stuck inside 'An najma' or the Star where he was working during its collapse. The whole building from its creation to destruction symbolizes diasporic community's position in al-Ghazira. It has been said that engineers from different parts of the world 'England or India, or Egypt, America, Korea, Pakistan who knows where' made the building and mixed sand instead of enough cement while making, for making their own profit and that caused the collapse. Alu did not die as he was skilled enough surviving in great difficulties and he came out as an idealist like his uncle Balaram Bose and discovered that the ultimate dirt of the earth remains in money or capital and that should be removed. Another cause of its fall was 'nobody wanted it to stand', though many people worked there nobody belonged there. Alu and Zindi with their whole group were literally chased by Jyoti Das with the help of Joy Lal. Their life in al-Ghazira ended on that day leaving 
Karthamma and Abu Fahal dead as five of them could manage to escape from there.

They first went to Zindi's village, near Damanhour but could not stay in her house: 'the house that Zindi's brothers had built with her Ghaziri dirhams'. Zindi's imaginative home was completely different from the real one. She is a different Zindi here.

... stripped, revealed as nothing but Fatheyya, plain old Fatheyya Ummnobody, mother of nothing, poor, simple, barren Fatheyya who was once abandoned in Alexandria by a child-hungry husband. Nothing she took with her could shut her ears to the cries of her brother's wives, the roar which shook the dead cotton bushes in the fields and creaked in the canals with the Kabais: Fatheyya the whore is gone at last, shukur Illah! (Ghosh 322)

Refused by the family members Zindi comes to Alexandria with all of them where Abu Fahal and Zaghloul 'spotted the fine two-storey houses their fathers and Abusa's father had built with their Ghazira-earned money'. But while Kulfi was buying a comb in Alexandria Alu and Zindi saw the 'Birdman' looking for them and the next morning Zindi went to one of her friends in Muharram Bey, and 'she had them stamped for every country she could think of'. After meeting the Birdman again in front of a Greek restaurant at Mohattat ar-Raml in Alexandria they decided to board on Virat Singh's Zeynab which was heading to Lisbon. Having a perilous journey there almost similar to Mariama they were forced to get down in Tunis because "there was an Indian on the bridge, some kind of policeman, who was insisting that the ship be searched for stowaways" (366). With the help of a few friends, and a little money, Virat Sing smuggles Zindi, Boss, Alu and Kulfi off the ship and through the port, to the vast football-field width of the Place d'Afrique. And Virat Singh assures the distressed souls, "I'll be back. The ship will be in Tangier exactly three weeks from now, on its way to Port Said and Bombay. He says, "If you need help meet me there" (366). They also meet Jyoti Das two times in Tunis and they become desperate to get rid of him and Zindi says we have to go more to the West to the border. "There was only one hope now: the border. The border it had to be; safety lay on the other side, in the vast welcoming emptiness of 
the Sahara" (367). And after long, struggling, 'deadly, poisonous, son-of-a-bitch' ten days they meet Mrs. Verma in the sun dune desert city of El Oued, north- eastern edge of the Algerian Sahara.

The members of Indian diasporic community in El Oued are five in numbers. There is Miss Krishnaswamy, she is a nurse; there is Dr. Mishra, the brilliant senior most, he is a surgeon, his wife, who is not a doctor and they are from Lucknow. And there are Dr. Uma Verma who is a microbiologist, and her husband who is also a doctor in ENT. Ghosh does not miss the opportunity to lay few strokes of their diasporic lives over there, expressed in a speech made by Dr. Mishra where some of their Algerian colleagues were present including the Indian folk.

He commented on the good sense of the Algerian Government in compulsorily repatriating half their salaries to India in foreign exchange. It showed, he said, a genuine understanding of the needs of developing nations (tactfully he said nothing about how the French doctors in Algeria were paid much more than they were, simply for being French). (Ghosh 375)

It expresses the position of Indian professionals in a foreign land in comparison with other diasporic community.

Kulfi's death, in a foreign land like El Oued and all the controversies regarding the issue points to us how diaspora deprives a person from a proper funeral. At the same time, Mrs. Verma's 'doing with what we have or replacing Ganga Jal with carbolic acid' states the positive side and ultimate hope of diasporic condition. As the novel ends in Alu Zindi and Boss along with the Birdman Jyoti Das looking towards the Atlantic '... hope is the beginning'.

Through these manifestations this paper exemplifies how an already established traditional society was deliberately destroyed by introducing newer trade. Colonial power and knowledge worked as a deciding factor to wipeout weaving from Indian Subcontinent and the movement of people was a by- product phenomenon. 


\section{Works Cited}

Alam, Fakrul. Imperial Entanglements and Literature in English. Dhaka: writers.ink, 2007. Print.

Bhabha, Homi K. "Cultural Diversity and Cultural Differences”. Ed. Bill Ashcroft, Gareth Griffiths, and Helen Tiffin. The Post-Colonial Studies Reader. London: Routledge, 1995. 206-209. Print.

---. "Of mimicry and man: The ambivalence of colonial discourse." The Location of Culture. New York: Routledge, 1994.121-131. Print.

Chambers, Claire. "Historicizing Scientific Reason in Amitav Ghosh's The Circle of Reason." Amitav Ghosh A Critical Companion. Ed. Tabish Khair. Delhi: Permanent Black, 2003. 36-55. Print.

Dixon, Robert. "'Travelling in West': The writing of Amitav Ghosh." Amitav Ghosh A Critical Companion. Ed. Tabish Khair. Delhi: Permanent Black, 2003. 9-35. Print. Ghosh, Amitav. The Circle of Reason. New Delhi: Ravi Dayal, 1986. Print. 